Abstract 11 Table 1 Prevalence of atrial fibrillation in patients with heart failure according to age groups

\begin{tabular}{|l|c|c|c|}
\hline & Heart Failure & Atrial Fibrillation & Mean Age \\
& Patients (\%) & $\%$ & (Years) \\
\hline All age groups & $31760(100.0)$ & 34.6 & 73.6 \\
\hline Age group 18-29 years & $256(0.8)$ & 8.6 & 24.2 \\
\hline Age group 30-39 years & $528(1.7)$ & 8.1 & 35.4 \\
\hline Age group 40-49 years & $1158(3.6)$ & 12.8 & 45.2 \\
\hline Age group 50-59 years & $2571(8.1)$ & 21.5 & 55.2 \\
\hline Age group 60-69 years & $5423(17.1)$ & 29.0 & 65.0 \\
\hline Age group 70-79 years & $9743(30.7)$ & 36.8 & 74.8 \\
\hline Age group 80-89 years & $9503(29.9)$ & 42.4 & 84.0 \\
\hline Age group 90-99 years & $2533(8.0)$ & 40.5 & 92.6 \\
\hline Age group $\geq 100$ years & $45(0.1)$ & 42.2 & 101.8 \\
\hline
\end{tabular}

important to appreciate whilst optimising heart failure medications in elderly patients.

\section{ANALYSIS OF THE EVOLUTION OF MIOCARDIAL INFARCTION AND HEART FAILURE EPIDEMIOLOGIES IN BRAZIL FROM 1998 TO 2015}

${ }^{1}$ Vinicius Oliveira Rocha Rodrigues*, 'Marcello Augusto Afonso de Oliveira, ${ }^{2}$ Victor Ludwig Gondim de Oliveira. ${ }^{1}$ Universidade Federal do Parana; ${ }^{2}$ Escola Bahiana de Medicina e Saude Publica; *Presenting Author

\subsection{6/heartjnl-2016-309890.12}

Introduction Coronary heart disease and its most common complication, myocardial infarction, are among the main causes of mortality in Brazil. Despite its severeness, the mortality rates for myocardial infarction are decreasing all over the world due to better treatment and management of the disease on its acute presentation. The damage caused by the ischaemia and tissue necrosis from the coronary disease is one of the main causes of heart failure, a disease associated with poor prognosis despite of the development of many novel treatment options in the last two decades. The current trend in the developed countries is an increase in the number of heart failure cases, which can be explained by increasing on survival to the acute presentation of heart disease. In this study, our team analysed the Brazilian trend for heart failure and myocardial infarction mortalities in order to see if it corresponds to what is expected for the world population.

Methods In our ecologic observational study, mortality rate was defined as the ratio between the number of deaths and the number of authorized hospital admission, with results multiplied by 100. Data were obtained from DATASUS, a Brazilian epidemiologic database organized by the Ministry of Health. Both health conditions analysed were selected based on the CID BR-10 classification. Our study comprised mortality rate data for the month of January of each year from 1998 to 2015.
Results Myocardial infarction still has higher mortality rates than heart failure, but results show a constant decline in its mortality statistics in the analysed period. In 1998, the mortality rate for myocardial infarction in Brazil was 17.95. Today, the country reached a rate of 11.80 , approximately $65 \%$ of the first measure. On the other hand, heart failure mortality increased from 6.63 in 1998 to 10.36 in 2015, an increase of $56 \%$.

Conclusion Our results suggest that the gap between mortality in myocardial infarction and heart failure is becoming narrower in Brazil, with a trend for an increase in mortality caused by heart failure and a decrease in mortality caused by myocardial infarction. This effect is probably caused by better treatment of the disease in Brazil in the last decades, with better treatment options and better training of health professionals. Heart failure, on the other hand, is becoming more common in part due to an increase in the survival from acute presentations of heart disease that can lead to this condition. This trend is similar to what is happening in the most developed countries, where this process is already more consolidated, and could indicate that the development of the Brazilian economy is reflecting in its health indicators.

Abstract 12 Table 1 Mortality rates for myocardial infarction and heart failure from 1998 to 2015

\begin{tabular}{llllll}
\hline Year & $\begin{array}{l}\text { Myocardial } \\
\text { infarction }\end{array}$ & $\begin{array}{l}\text { Heart } \\
\text { failure }\end{array}$ & Year $\begin{array}{l}\text { Myocardial } \\
\text { infarction }\end{array}$ & $\begin{array}{l}\text { Heart } \\
\text { failure }\end{array}$ \\
\hline 1998 & 17.95 & 6.63 & 2007 & 13.48 & 7.68 \\
1999 & 17.07 & 6.31 & 2008 & 14.62 & 6.91 \\
2000 & 15.13 & 6.39 & 2009 & 12.90 & 8.19 \\
2001 & 16.99 & 6.36 & 2010 & 12.21 & 8.80 \\
2002 & 15.84 & 6.90 & 2011 & 13.32 & 9.29 \\
2003 & 14.31 & 6.99 & 2012 & 12.01 & 8.72 \\
2004 & 14.82 & 7.10 & 2013 & 11.86 & 9.40 \\
2005 & 13.93 & 7.24 & 2014 & 11.35 & 9.07 \\
2006 & 13.96 & 7.83 & 2015 & 11.80 & 10.36 \\
\hline
\end{tabular}

